\title{
KAITAN ANTARA DEPRESI DAN STATUS GIZI PADA \\ LANSIA DI UPT PELAYANAN SOSIAL TRESNA WERDHA JEMBER
}

\author{
Yuli Indarti \\ Fakultas FTIK, IAIN Jember \\ yuli.indarti@iain-jember.ac.id \\ Fuadatul Huroniyah \\ Fakultas Dakwah, IAIN Jember \\ f.huroniyah@gmail.com
}

\begin{abstract}
Abstrak:
Peningkatan usia harapan hidup penduduk menyebabkan jumlah penduduk lanjut usia terus meningkat dari tahun ke tahun. Lansia adalah individu yang mengalami proses penuaan sehingga rentan terhadap penyakit. Berbagai kondisi pada masa lanjut usia khususnya status gizi mungkin menunjukkan keterkaitan dengan kesehatan mental. Pendekatan penelitian yang digunakan adalah kuantitatif, dengan desain cross sectional. Populasi penelitian adalah lansia yang tinggal panti werdha UPT. Tresna Werdha Jember. Pengambilan sampel dilakukan dengan purposive sampling. Instrumen pengumpulan data dalam penelitian ini menggunakan metode observasi, dokumentasi dan angket. Analisis data yang digunakan adalah univariat, bivariat dan multivariat dengan menggunakan program SPSS. Hasil penelitian ini dapat simpulkan : (1). Tidak ditemukan kaitan status gizi dan tingkat depresi. Artinya status gizi lansia tidak berpengaruh terhadap tingkat depresi pada lansia atau sebaliknya (2) Hasil uji statistik menggunakan regresi logistic berganda menunjukkan bahwa karakteristik responden (jenis kelamin, umur, agama, status pernikahan, status gizi) tidak berpengaruh terhadap tingkat depresi, namun terdapat dua karakteristik yang berpengaruh pada tingkat depresi pada lansia yaitu pendidikan dan kepemilikan penyakit. Kesimpulannya, tidak ada kaitan status gizi dan tingkat depresi.
\end{abstract}

Kata Kunci : Lansia, status giri,kepemilikan penyakit, depresi

\begin{abstract}
:
The increase in life expectancy of the population causes the number of elderly people to continue to increase from year to year. Elderly are individuals who experience an aging process so they are susceptible to disease. Various conditions in old age, especially nutritional status, may show an association with mental health. The research approach used is quantitative, with with a cross sectional design.. The study population is the elderly who live in the UPT Tresna Werdha Jember nursing home. Sampling was done by purposive sampling. The data collection instrument in this study used the method of observation, documentation and questionnaires. The data analysis used was univariate, bivariate and multivariate using the SPSS program. The results of this study can be concluded: (1). There was no association between nutritional status and depression level. This means that the nutritional status of the elderly has no impact on the level of depression in the elderly. (2) The results of statistical tests using multiple logistic regression indicate that the characteristics of the respondent (gender, age, religion, marital status, nutritional status) bave no effect on the level of depression, but there are two characteristics that influence the level of depression in the elderly, which are education and disease. The conclusion is there was no association between nutritional status and depression level.
\end{abstract}

Keywords: Elderly, nutritional status, disease, depression

FENOMENA, Vol. 20 No. 1 (Januari - Juni 2021) | 115 


\section{Kaitan Antara Depresi Dan Status Gizi Pada Lansia Di UPT Pelayanan Sosial ...}

\section{Pendahuluan}

Keberhasilan pembagunan kesehatan membawa dampak pada peningkatan kualitas hidup penduduk Indonesia. Keberhasilan program pembangunan terebut salah satunya diukur dengan meningkatnya Usia Harapan Hidup (UHH), dimana di Indonesia pada tahun 2019, UHH penduduk 71,3 tahun dan angka tersebut meningkat dari tahun 2015 sebesar 70,8 tahun ${ }^{1}$. Peningkatan usia harapan hidup membawa implikasi meningkatnya jumlah penduduk lanjut usia (60 tahun ke atas) dari tahun ke tahun. Berdasarkan data Sensus Penduduk tahun 2019 persentase penduduk lansia Indonesia meningkat menjadi 9,78\% dari 7,59\% pada tahun $2010^{2}$. Peningkatnya angka harapan hidup dan jumlah lansia tersebut menyebabkan meningkatkatnya permasalahan sosial yang membawa implikasi pada program pelayanan sosial/kesehatan yang harus disediakan..

Lansia adalah individu yang mengalami proses penurunan daya tahan fisik sehingga rentan terhadap penyakit. Bertambahnya jumlah lansia di Indonesia akan membawa pengaruh pada beban sumber daya untuk mempertahankan kesehatannya. Penyakit pada lansia erat kaitannya dengan masalah gizi, baik gizi kurang maupun gizi lebih. Berbagai penelitian menunjukkan bahwa zat gizi, baik zat gizi makro maupun mikero, menunjukkan keterkaitan pada kesehatan. Penelitian menunjukkan siswa dengan depresi memiliki asupan antioksidan makanan yang lebih rendah secara signifikan.daripada siswa tidak depresi ${ }^{3}$. Penelitian juga menunjukkan bahwa terdapat hubungan antara asupan sayuran dan prevalensi gejala depresi pada wanita paruh baya ${ }^{4}$.

Padahal hasil penelitian menunjukkan bahwa gizi kurang juga menjadi masalah kesehatan pada lansia. Misalnya .survei di Panti Werdha Kabupaten Lhokseumawe menunjukkan bahwa menunjukkan 44,4\% lansia mengalami resiko malnutrisi dan 37,1\% malnutrisi ${ }^{5}$. Kekurangan zat gizi, baik makro dan mikro, bisa dimanifstasikan dalam status gizi anthropometri khususnya karena status gizi kurang/buruk, karena kekurangan zat gizi makro biasanya diiringi dengan zat gizi mikro. Keterkaitan status gizi dan kesehatan mental, tidak hanya status gizi sebagai faktor resiko kesehatan mental, tetapi juga sebagai dampak dari permasalahan mental karena asupan gizi terkait dengan selera makan.

\footnotetext{
${ }^{1}$ Badan Pusat Statistika, "Statistik Indonesia 2020 Statistical Yearbook of Indonesia 2020," Statistical Yearbook of Indonesia, no. April (2020): 192.

${ }^{2}$ Ibid.

${ }^{3}$ Mohammad Prohan et al., "Total Antioxidant Capacity of Diet and Serum, Dietary Antioxidant Vitamins Intake, and Serum Hs-CRP Levels in Relation to Depression Scales in University Male Students," Redox Report 19, no. 3 (2014): 133-139.

${ }^{4}$ S. Mihrshahi, A. J. Dobson, and G. D. Mishra, "Fruit and Vegetable Consumption and Prevalence and Incidence of Depressive Symptoms in Mid-Age Women: Results from the Australian Longitudinal Study on Women's Health," European Journal of Clinical Nutrition 69, no. 5 (2015): 585-591.

${ }^{5}$ EK Khusumawardani and M e u t i a M., "Status Gizi Lansia Berdasarkan Mini Nutritional Assessment ÎMNAÒ Di Panti Sosial Tresna Werdha Lhokseumawe-Aceh Utara," Jurnal S A M U E R A 9, no. 2 (2015): 29-40, http://marefateadyan.nashriyat.ir/node/150.
} 
Selain hal tersebut berdasarkan data dari Riskesdas tahun 2018, prevalensi depresi pada penduduk usia $\geq 15$ tahun di Indonesia adalah $6,1 \%{ }^{6}$. WHO memperkirakan bahwa pada tahun 2020 depresi menempati ranking ke dua dari beban penyakit global. Pada tahun 2030 diperkirakan depresi akan menjadi penyebab utama bagi gangguan kesehatan ${ }^{7}$. Depresi juga menjadi gangguan mental yang paling umum di banyak negara. Prevalensi depresi pada lansia di dunia menunjukkan hasil yang bervariasi. Menurut Sari et al pada lansia yang tinggal di panti werdha 52,5\% mengalami depresi ringan dan 10\% mengalami depresi sedang ${ }^{8}$. Hal ini berbeda dari lansia yang tinggal bersama keluarga dimana hanya 20\% yang mengalami depresi ringan serta 1\% mengalami depresi berat. Adanya kecenderungan penderita depresi yang tidak memperhatikan pola makan dan aktivitas fisiknya menyebabkan kenaikan atau penurunan berat badan, sehingga kemungkinan faktor tersebut berperan menentukan status gizi.

Untuk mengantisipasi permasalahan tersebut, diperlukan adanya perubahan program pelayanan yang khusus pada penduduk lanjut usia. Menyikapi arah perubahan paradigma pelayanan yang menjunjung harkat manusia dan berorientasi pada kinerja diperlukan input/data dasar yang berguna untuk menghasilkan program yang tepat sasaran dan kualitas yang memadai. Adanya data dasar dari status gizi yang dihadapi oleh lansia khususnya di panti sosial dan keterkaitannya dengan depresi diperlukan untuk memahami permasalahan tersebut.

Tujuan dari penelitian ini adalah untuk mendiskripsikan kaitan antara status gizi dengan tingkat depresi pada lansia yang dirawat di UPT Pelayanan Sosial Tresna Werdha Kabupaten Jember khususnya untuk mengetahui kaitan karakteristik responden (umur, jenis kelamin, pendidikan, status pernikahan, keberadaan penyakit status gizi) dengan tingkat depresi pada lansia di UPT Pelayanan Sosial Tresna Werdha Kabupaten Jember dan mengetahui kaitan status gizi dan tingkat depresi pada lansia di UPT Pelayanan Sosial Tresna Werdha Kabupaten Jember

\section{METODE}

Desain Penelitian

Penelitian ini menggunakan pendekatan kuantitatif dengan jenis penelitian cross sectional Populasi dan Sampel Penelitian

\footnotetext{
${ }^{6}$ Balitbang Kemenkes RI, Laporan Hasil Riset Kesehatan Dasar (Riskesdas) 2018, 2019.

7 UNAIDS, "Global Standards for Quality Health-Care Services for Adolescents: A Guide to Implement a Standards-Driven Approach to Improve the Quality of Health Care Services for Adolescents," World Health Organization 1 (2015): 1-40, http://apps.who.int/iris/bitstream/10665/183935/1/9789241549332_vol1_eng.pdf.

8 Rima Sari, Arneliwati, and Sri Utami, "Perbedaaan Tingkat Depresi Antara Lansia Yang Tinggal Di PSTW Dengan Lansia Yang Tinggal Di Tengah Keluarga” 2, no. 2 (2015).
} 
Populasi pada penelitian ini adalah seluruh lansia yang tinggal panti werdha UPT Tresna Werdha Jember, pengambilan sampel dilakukan dengan purposive sampling, dimana sampel adalah lansia penghuni di panti werdha yang menjadi lokasi penelitian yang memenuhi kriteria inklusi.

Pengumpulan Data

Pengumpulan data dalam penelitian ini menggunakan beberapa metode diantaranya : metode observasi, metode dokumentasi, dan metode angket.

1. Metode Observasi.

Metode observasi adalah pengamatan atau pencatatan secara sistematis fenomena-fenomena kegiatan yang sedang berlangsung atau tidak berlangsung. Metode perlu digunakan karena penelitian ini bersifat fenomenologis.

2. Metode Dokumentasi

Metode Dokumenter atau dekumentasi adalah suatu metode yang digunakan untuk mencari data mengenai hal-hal atau variabel yang berupa catatan, transkrip, buku, surat kabar, majalah, prasasti, notulen rapat, agenda dan sebagainya.

3. Metode Angket.

Penggunaan metode ini dibagi menjadi dua bagian, yaitu :

a. Angket yang pertama ; angket yang mengungkap identitas subjek dan status gizi lansia seperti ; nama, usia, pendidikan, status perkawinan, suku, riwayat kesehatan pada lansia.

b. Angket kedua ; yang memberikan informasi tentang tingkat depresi pada lansia

Analisis Data

Analisisis data dilakukan secara univariat dan bivariat dan multivariat, dengan menggunakan program SPSS. Pengujian hipotesis berdasarkan pada parametrik dan powerfull statistik dengan alasan generalisasi hasil penelitian yang diperoleh dapat maksimal dan diharapkan dapat terpenuhi semua uji asumsi yang meliputi uji normalitas sebaran data, maupun uji linieritas hubungan antar variabel. Pengujian semua hipotesis menggunakan taraf signifikansi $5 \%$ dan analisisnya menggunakan analisis multiple regresi logistic.

Disamping itu juga dilakukan Analisis univariat untuk memberikan gambaran karakteristik subyek penelitian. Uji bivariat dilakukan dengan menggunakan uji analisis regresi linear untuk mengetahui hubungan antara variabel yang diteliti. Uji multivariate dilakukan dengan 
menggunakan uji multiple regression menggunakan program komputer Statistical Programme for Social Sciences (SPSS) release 16 for Windows.

\section{HASIL}

A. Karakteristik Responden

Statistik deskriptif digunakan untuk mengetahui karakteristik dan informasi mengenai penghuni panti. Informasi yang didapatkan yaitu mengenai jenis kelamin, umur, agama, pendidikan, pernikahan, suku bangsa, keberadaan penyakit, tingkat nutrisi dan status depresi sebagai variabel respon

a. Tingkat depresi

Variabel respon yang digunakan dalam analisis ini yaitu mengenai kondisi tingkat depresi penghuni panti di Puger. Hasil survey menunjukkan dari 54 penghuni panti, tercatat 20 tidak/depresi ringan (37\%) serta 34 depresi sedang (63\%), untuk tingkat depresi berat tidak ada.

b. Jenis kelamin

Tabel diatas menunjukkan bahwa jenis kelamin penghuni panti lebih banyak perempuan yaitu sebesar 28 orang dan laki-laki sebanyak 26 orang dengan prosentase perempuan 51,9\% dan laki-laki 48,1\%.

c. Umur

Berdasarkan tabel diatas kebanyakan penghuni panti berumur 60-74 tahun yang masuk kategori umur enderly yaitu sebanyak 42 orang, sedangkan kategori umur tua yaitu 75-90 tahun sebanyak 12 orang jadi sedikit sekali yang masuk kategori tua. Dengan prosentase 77,8\% kategori umur enderly dan tua sebesar 22,2\%. Untuk yang kategori very old tidak ada.

d. Jenis agama

Dari jenis agama berdasarkan tabel di atas hampir semua penghuni panti beragama Islam yaitu sebesar 52 orang dengan prosentase $96.3 \%$ hanya 2 orang yang beragama kristen/katolik yaitu sebesar 3,7\%.

e. Pendidikan

Berdasarkan tabel diatas kebanyakan penghuni panti hanya tamatan SD terbukti diperoleh sebanyak 22 orang sedangkan yang tidak tamat SD sebanyak 18 orang. Hanya sedikit sekali yang tamatan SMP dan SMA yaitu sebanyak 5 orang yang tamatan SMP dan 9 orang yang tamatan SMA. Dengan urutan prosentase tidak tamat SD 33,3\%, tamat SD 40,7\%, tamat SMP 9,3\% dan tamat SMA 16,7\%.

f. Status Pernikahan 
Sebagian besar penghuni panti berstatus janda/duda, sebesar 36 orang dengan prosentase $66,7 \%$. sedangkan yang tidak menikah sangat sedikit dibandingkan dengan yang menikah yaitu sebanyak 5 orang yang tidak menikah dan yang menikah 13 orang dengan prosentase berturu-tirut sebesar 9,3\% dan yang menikah 24,1\%.

g. Suku Bangsa

Berdasarkan tabel diatas diperoleh penghuni panti yang bersuku Jawa sebanyak 45 orang dengan prosentase $83.3 \%$, suku Madura 6 orang dengan prosentase $11.1 \%$, suku Bugis / Makassar 2 orang dengan prosentase $3.7 \%$, suku Sunda dengan prosentase $1.9 \%$.

h. Keberadaan penyakit

Berdasarkan tabel diatas diperoleh penghuni panti yang memiliki penyakiit 45 orang dengan prosentase $83.3 \%$, sedangkan yang tidak memiliki penyakit sebanyak 9 orang dengan prosentase $16.7 \%$,

\section{i. Status Gizi}

Berdasarkan tabel diatas diperoleh penghuni panti dengan tingkat gizi yang kurang sebanyak 4 orang dengan prosentase 7,4\%, resiko gizi kurang sebanyak 23 orang dengan prosentase $42.6 \%$, sedangkan gizi baik sebanyak 27 orang dengan prosentase $50 \%$

Dalam penelitian ini analisis regresi logistik digunakan untuk mengetahui pola hubungan antara variabel dependen dan variabel independen. Dalam penelitian ini yang menjadi variabel dependen adalah status depresi. Sedangkan, yang menjadi variabel independen adalah variabel yang diduga menjadi faktor-faktor penyebab kondisi depresi.

Regresi logistik tunggal digunakan untuk mengetahui pengaruh faktor-faktor yang diduga mempengaruhi kondisi status depresi terhadap status depresi secara individu. Menggunakan statistik uji Wald dibandingkan dengan nilai $Z$ tabel dengan kriteria pengambilan keputusan apabila nilai Wald lebih besar dari Z tabel maka Hipotesis awal ditolak. Hipotesis awal nya adalah tidak ada pengaruh faktor-faktor status depresi terhadap status depresi, sebaliknya hipotesis tandinganya terdapat pengaruh faktor-faktor status depresi terhadap status depresi.

Secara Individu, berikut tabel hasil pengaruh faktor-faktor resiko depresi terhadap status depresi 


\begin{tabular}{|c|c|c|c|c|c|c|c|}
\hline & & B & S.E. & Wald & df & Sig. & $\operatorname{Exp}(B)$ \\
\hline \multirow[t]{2}{*}{ Step 1a } & $\mathrm{X} 1(1)$ & .201 & .565 & .126 & 1 & .723 & 1.222 \\
\hline & Constant & .435 & .387 & 1.266 & 1 & .261 & 1.545 \\
\hline \multirow[t]{2}{*}{ Step 1a } & $\mathrm{X} 2(1)$ & -.208 & .690 & . 091 & 1 & .763 & .813 \\
\hline & Constant & .693 & .612 & 1.281 & 1 & .258 & 2.000 \\
\hline \multirow[t]{2}{*}{ Step 1a } & X3(1) & .552 & 1.443 & .146 & 1 & .702 & 1.737 \\
\hline & Constant & .000 & 1.414 & .000 & 1 & 1.000 & 1.000 \\
\hline \multirow[t]{5}{*}{ Step 1a } & $\mathrm{X} 4$ & & & 2.170 & 3 & .538 & \\
\hline & $\mathrm{X} 4(1)$ & .229 & .827 & .077 & 1 & .782 & 1.257 \\
\hline & $\mathrm{X} 4(2)$ & .758 & .824 & .845 & 1 & .358 & 2.133 \\
\hline & $\mathrm{X} 4(3)$ & -.629 & 1.133 & .308 & 1 & .579 & .533 \\
\hline & Constant & .223 & .671 & .111 & 1 & .739 & 1.250 \\
\hline \multirow[t]{4}{*}{ Step 1a } & $\mathrm{X} 5$ & & & .043 & 2 & .979 & \\
\hline & $\mathrm{X} 5(1)$ & -.065 & 1.076 & .004 & 1 & .952 & .938 \\
\hline & $\mathrm{X} 5(2)$ & .101 & .667 & .023 & 1 & .880 & 1.106 \\
\hline & Constant & .470 & .570 & .680 & 1 & .410 & 1.600 \\
\hline \multirow[t]{5}{*}{ Step 1a } & $\mathrm{X} 6$ & & & .187 & 3 & .980 & \\
\hline & $\mathrm{X} 6(1)$ & 21.798 & $4.019 \mathrm{E} 4$ & .000 & 1 & 1.000 & $2.928 \mathrm{E} 9$ \\
\hline & $\mathrm{X} 6(2)$ & 21.896 & 4.019E4 & .000 & 1 & 1.000 & $3.231 \mathrm{E} 9$ \\
\hline & X6(3) & 21.203 & 4.019E4 & .000 & 1 & 1.000 & $1.615 \mathrm{E} 9$ \\
\hline & Constant & -21.203 & 4.019E4 & .000 & 1 & 1.000 & .000 \\
\hline \multirow[t]{2}{*}{ Step 1a } & $\mathrm{X} 7(1)$ & .916 & .742 & 1.527 & 1 & .217 & 2.500 \\
\hline & Constant & -.223 & .671 & .111 & 1 & .739 & .800 \\
\hline \multirow[t]{4}{*}{ Step 1a } & $\mathrm{X} 8$ & & & .450 & 2 & .798 & \\
\hline & $\mathrm{X} 8(1)$ & .724 & 1.219 & .352 & 1 & .553 & 2.062 \\
\hline & $\mathrm{X} 8(2)$ & .254 & .587 & .187 & 1 & .666 & 1.289 \\
\hline & Constant & .375 & .392 & .915 & 1 & .339 & 1.455 \\
\hline
\end{tabular}

Tabel diatas menjelaskan bahwa dari enam variabel yang diduga berpengaruh terhadap status depresi, hanya dua variabel yang berpengaruh secara nyata dengan nilai signifikansi dibawah 20\% ( $\alpha=20 \%$ ). Sedangkan uji wald mempunyai hasil yang sama yang berpengaruh secara nyata dengan besar lebih dari 1.28 (nilai $\mathrm{Z}$ table). Hal ini menyebabkan dapat digunakan untuk membentuk uji serentak. Dua variabel yang signifikan yaitu pendidikan dan keberadaan penyakit.

Pengaruh dari kedua faktor tersebut dapat dijelaskan sebagai berikut.

1) Pendidikan 
Pendidikan penghuni panti SD/SR, SMP dan SMA mempunyai kondisi tingkat depresi lebih baik sebesar 2,17 kali dari pendidikan penghuni panti dengan tingkat pendidikan yang tidak tamat SD.

2) Keberadaan penyakit

Penghuni panti dengan status tidak mempunyai penyakit mempunyai kondisi tingkat status depresi lebih baik yaitu sebesar 1,53 kali dibandingkan dengan penghuni panti yang mempunyai penyakit.

B. Pengaruh Faktor-faktor yang diduga mempengaruhi tingkat depresi terhadap status depresi

Pembentukan model regresi logistik serentak bertujuan untuk memperoleh model yang tepat dan sederhana berdasarkan faktor-faktor tingkat depresi yang dianggap berpengaruh terhadap kondisi status depresi.

Untuk memeriksa keberartian koefisien beta secara serentak dilakukan pengujian dengan likelihood ratio test.

Dengan hipotesis awal tidak ada pengaruh antara tingkat pendidikan dan keberadaan penyakit terhadap status depresi, sedangkan hipotesis alternatifnya adalah terdapat pengaruh antara tingkat pendidikan dan keberadaan penyakit terhadap status depresi

Tabel pengaruh faktor-faktor tingkat depresi terhadap status depresi secara serentak.

\begin{tabular}{|c|c|c|c|c|c|c|c|}
\hline & & B & S.E. & Wald & df & Sig. & $\operatorname{Exp}(B)$ \\
\hline \multirow[t]{6}{*}{ Step $1^{\mathrm{a}}$} & X4 & & & 1.952 & 3 & .082 & \\
\hline & $\mathrm{X} 4(1)$ & .387 & .851 & .207 & 1 & .049 & 1.473 \\
\hline & X4(2) & .752 & .831 & .818 & 1 & .066 & 2.122 \\
\hline & X4(3) & -.567 & 1.147 & .245 & 1 & .021 & .567 \\
\hline & X7(1) & .875 & .774 & 1.378 & 1 & .058 & 2.399 \\
\hline & Constant & -.555 & .968 & .328 & 1 & .067 & .574 \\
\hline
\end{tabular}

a. Variable(s) entered on step 1: X4, X7.

Tabel di atas menunjukkan bahwa nilai signifikansi dari dua variabel independen yang masuk model, semuanya mempunyai nilai lebih kecil dari tingkat kemaknaan sehingga hipotesis awal ditolak sehingga menerima hipotesis alternatif artinya dua parameter variabel independen tersebut tidak sama dengan nol. Sehingga variabel independen dengan parameter signifikan yang secara bersama-sama mempengaruhi tingkat depresi yaitu pendidikan dan keberadaan penyakit rumah tangga. 
Secara bersama-sama kedua variabel independen tersebut mempengaruhi status depresi sebagai berikut :

1. Tingkat pendidikan

Variabel tingkat pendidikan secara bersama-sama signifikan terhadap kondisi tingkat depresi. Tingkat pendidikan lulusan SD, SMP dan SMU mempunyai kondisi tingkat depresi lebih kecil dengan nilai sebesar 1,473; 2, 122 dan 0,567 kali daripada penghuni panti yang tidak tamat SD.

2. Kepemilikan penyakit

Variabel kepemilikan penyakit secara bersama-sama signifikan terhadap status tingkat depresi. Penghuni panti yang tidak memiliki penyakit mempunyai kondisi tingkat depresi lebih kecil 2.399 kali dari pada penghuni panti yang mempunyai penyakit.

C. Model Regresi

Sedangkan model regresi logistic secara serentak yang terbentuk yaitu :

$$
\pi(x)=\frac{\exp \left(0,387 X_{4}(1)+0,752 X_{4}(2)-0,567 X_{4}(3)+0,875 X_{4}(4)+0,875 X_{7}(1)\right)}{1+\exp \left(0,387 X_{4}(1)+0,752 X_{4}(2)-0,567 X_{4}(3)+0,875 X_{4}(4)+0,875 X_{7}(1)\right)}
$$

Nilai tingkat pendidikan dan status tingkat depresi dijelaskan sebagai berikut :

1) Peluang tingkat pendidikan tidak tamat SMA mempunyai kondisi tingkat depresi yang signifikan sebesar 0.387 .

2) Peluang tingkat pendidikan SMP mempunyai kondisi tingkat depresi yang signifikan sebesar 0.750 .

3) Peluang tingkat pendidikan SD mempunyai kondisi tingkat depresi yang signifikan sebesar 0.567 .

4) Peluang tingkat pendidikan tidak tamat SD mempunyai kondisi tingkat depresi yang signifikan sebesar 0.875 .

5) Peluang keberadaan penyakit mempunyai kondisi tingkat depresi yang signifikan sebesar 0.875 .

D. Uji Kesesuaian Model

Untuk menguji kesesuaian model apakah model sesuai dalam artian tidak ada perbedaan antara hasil observasi dengan kemungkinan hasil prediksi model dilakukan dengan menggunakan hipotesis sebagai berikut : 
H0 : Model sesuai (tidak ada perbedaan antara hasil observasi dengan kemungkinan hasil prediksi model)

H1 : Model tidak sesuai (ada perbedaan antara hasil observasi dengan kemungkinan hasil prediksi model)

Statistik Uji chi square 0,763 lebih kecil dibandingkan dengan table chi square sebesar 3,219 Atau dapat dilihat dari nilai signifikansi sebesar 0,934 lebih besar dari nilai tingkat kemaknaan 0,05 , sehingga hipotesis awal diterima yang artinya model sesuai (tidak ada perbedaan antara hasil observasi dengan kemingkinan hasil prediksi).

Hosmer and Lemeshow Test

\begin{tabular}{|l|r|r|r|}
\hline Step & Chi-square & Df & \multicolumn{1}{c|}{ Sig. } \\
\hline 1 & .763 & & .943 \\
\hline
\end{tabular}

\section{PEMBAHASAN}

1. Kaitan Status Gizi dan Tingkat Depresi pada Lansia di UPT Pelayanan Sosial Tresna Werdha Kabupaten Jember

Berdasarkan hasil analisis hipotesis berdasarkan uji multiple regresi linier menunjukkan bahwa ada tidak ada keterkaitan yang signifikan antara status gizi dengan tingkat depresi pada lansia di UPT Pelayanan Sosial Tresna Werdha di Kabupaten Jember.. Hasil ini menunjukkan bahwa status gisi berdasarkarkan penurunan atau peningkatan status gizi pada lansia tidak diikuti dengan tingkat depresi lansia.

Hasil ini berbeda dengan penelitian yang dilakukan di UPTD Griya Werdha Surabaya dimana depresi berhubungan dengan status gizi lansia, dimana peluang lansia yang mengalami depresi 9,75 kali lebih besar untuk mengalami malnutrisi $[\mathrm{OR}=9,75,95 \% \mathrm{CI}=1,63$ $(1,45-1,81)]^{9}$ Keterkaitan asupan gizi orang dewasa dan kecenderungan depresi, penelitian menunjukkan bahwa diet pada orang dewasa dengan bipolar disorder cenderung pada pola diet gaya Barat ${ }^{10}$. Penderita gangguan bipolar cenderung memiliki kualitas pola makan yang

\footnotetext{
${ }_{9}$ Hasna Rosida Putri and Triska Susila Nindya, "Hubungan Kecenderungan Depresi Dengan Status Gizi Pada Lansia Di UPTD Griya Werdha Surabaya,” Media Gizi Indonesia 14, no. 1 (2019): 87-94.

${ }^{10}$ Felice N. Jacka et al., "Diet Quality in Bipolar Disorder in a Population-Based Sample of Women," Journal of Affective Disorders 129, no. 1-3 (2011): 332-337, http://dx.doi.org/10.1016/j.jad.2010.09.004.
} 
lebih buruk, daripada non bipolar, dengan asupan gula, lemak, dan karbohidrat yang tinggi 11

Hasil penelitian ini didukung oleh studi meta analysis. dimana asupan tinggi buah, sayuran. ikan dan biji-bijian, berhubungan dengan penurunan resiko depresi pada orang dewasa $^{12}$

2. Kaitan Karakteristik Responden (Jenis Kelamin, Umur, Agama, Pendidikan, Status Pernikahan, Keberadaan Penyakit dan Tingkat Depresi pada Lansia di UPT Pelayanan Sosial Tresna Werdha Kabupaten Jember

Berdasarkan hasil penelitian yang telah diperoleh, kaitan antara jenis kelamin dan tingkat depresi pada lansia di UPT Pelayanan Sosial Tresna Werdha Kabupaten Jember menunjukkan bahwa jenis kelamin tidak berkaitan dengan tingkat depresi pada lansia. Berdasarkan penelitian di panti werdha Surabaya juga ditemukan bahwa jenis kelamin tidak berpengaruh terhadap terjadinya depresi. ${ }^{13}$.

Hal yang sama juga terjadi kaitan antara umur, agama dan tingkat depresi pada lansia, hasil penelitian menunjukkan bahwa umur, agama, status pernikahan dan suku juga tidak berkaitan dengan depresi pada lansia. Penelitian sebelumnya juga menemukan bahwa umur tidak berpengaruh terhadap terjadinya depresi. ${ }^{14}$

Dari segi kaitan pendidikan dengan tingkat depresi lansia menunjukkan bahwa kebanyakan penghuni panti berpendidikan rendah. Terbukti tamatan SD sebanyak 22 orang sedangkan yang tidak tamat SD sebanyak 18 orang. Hanya sedikit sekali yang tamatan SMP dan SMA yaitu sebanyak 5 orang yang tamatan SMP dan 9 orang yang tamatan SMA. Dengan urutan prosentase tidak tamat SD 33,3\%, tamat SD 40,7\%, tamat SMP 9,3\% dan tamat SMA 16,7\%. Dari hasil uji analisis diperoleh bahwa tingkat pendidikan berpengaruh secara signifikan terhadap terjadinya depresi. Hal ini sesuai dengan penelitian yang dilakukan di panti werdha Samarinda ${ }^{15}$.

Sebagian besar penghuni panti berstatus janda/duda hal ini dengan prosentase $66,7 \%$ (36 orang). Sedangkan yang tidak menikah lebih sedikit dibandingkan dengan yang menikah

${ }^{11}$ John L. Beyer and Martha E. Payne, "Nutrition and Bipolar Depression," Psychiatric Clinics of North America 39, no. 1 (2016): 75-86, http://dx.doi.org/10.1016/j.psc.2015.10.003.

12 Jun S. Lai et al., "A Systematic Review and Meta-Analysis of Dietary Patterns and Depression in CommunityDwelling Adults," American Journal of Clinical Nutrition 99, no. 1 (2014): 181-197.

13 Putri and Nindya, "Hubungan Kecenderungan Depresi Dengan Status Gizi Pada Lansia Di UPTD Griya Werdha Surabaya."

14 Ibid.

15 In Driyani, "Hubungan Antara Gambaran Karakteristik Responden Dan Dukungan Sosial Dengan Tingkat Depresi Pada Lanjut Usia Di PSTW Nirwana Puri Samarinda,” Skripsi (2016): 1-28. 
masing-masing sebanyak 9,3\% (5 orang) dan 24,1\% (13 orang). Hasil uji analisis menunjukkan bahwa status pernikahan tidak berkaitan dengan depresi. Demikian juga penelitian oleh Driyani ${ }^{16}$.

Begitu pula kaitan suku bangsa dengan tingkat depresi lansia. Data yang diperoleh menunjukkan bahwa penghuni panti yang bersuku Jawa sebanyak 45 orang dengan prosentase $83.3 \%$, suku Madura 6 orang dengan prosentase 11.1\%, suku Bugis/Makassar 2 orang dengan prosentase $3.7 \%$, suku Sunda dengan prosentase 1.9\%. Hasil uji statistik tidak menunjukkan ada kaitan antara suku bangsa dan tingkat depresi.

Berdasarkan data diperoleh penghuni panti yang memiliki penyakiit 45 orang dengan prosentase $83.3 \%$, sedangkan yang tidak memiliki penyakit sebanyak 9 orang dengan prosentase 16.7\%. Hasil uji statistik menunjukkan terdapat kaitan antara keberadaan penyakit dan depresi.

\section{SIMPULAN}

Berdasarkan hasil yang telah diperoleh dilapangan, maka dapat ditarik kesimpulan yaitu: Tidak ditemukan kaitan status gizi dan tingkat depresi pada lansia di UPT Pelayanan Sosial Tresna Werdha Kabupaten Jember.

Hasil penelitian juga menemukan, bahwa secara bersama-sama tidak ada kaitan karakteristik responden (jenis kelamin, umur, agama, pendidikan, status pernikahan, keberadaan penyakit, status gizi) terhadap tingkat depresi pada lansia di UPT Pelayanan Sosial Tresna Werdha Kabupaten Jember. Namun, ada dua karakteristik yang berpengaruh pada tingkat depresi pada lansia, yaitu pendidikan dan kepemilikan penyakit.

\section{DAFTAR PUSTAKA}

Badan Pusat Statistika. “Statistik Indonesia 2020 Statistical Yearbook of Indonesia 2020.” Statistical Yearbook of Indonesia, no. April (2020): 192.

Balitbang Kemenkes RI. Laporan Hasil Riset Kesehatan Dasar (Riskesdas) 2018, 2019.

Beyer, John L., and Martha E. Payne. "Nutrition and Bipolar Depression." Psychiatric Clinics of North America 39, no. 1 (2016): 75-86. http://dx.doi.org/10.1016/j.psc.2015.10.003.

Driyani, In. "Hubungan Antara Gambaran Karakteristik Responden Dan Dukungan Sosial Dengan Tingkat Depresi Pada Lanjut Usia Di PSTW Nirwana Puri Samarinda.” Skripsi (2016): 1-28. Jacka, Felice N., Julie A. Pasco, Arnstein Mykletun, Lana J. Williams, Geoffrey C. Nicholson, Mark

16 Ibid.

126 | FENOMENA, Vol. 20 No. 1 (Januari - Juni 2021) 
A. Kotowicz, and Michael Berk. "Diet Quality in Bipolar Disorder in a Population-Based Sample of Women." Journal of Affective Disorders 129, no. 1-3 (2011): 332-337. http://dx.doi.org/10.1016/j.jad.2010.09.004.

Khusumawardani, EK, and M e u t i a M. "Status Gizi Lansia Berdasarkan Mini Nutritional Assessment Î MNAŌ Di Panti Sosial Tresna Werdha Lhokseumawe-Aceh Utara.” Jurnal S A M U D E R A 9, no. 2 (2015): 29-40. http://marefateadyan.nashriyat.ir/node/150.

Lai, Jun S., Sarah Hiles, Alessandra Bisquera, Alexis J. Hure, Mark McEvoy, and John Attia. "A Systematic Review and Meta-Analysis of Dietary Patterns and Depression in CommunityDwelling Adults." American Journal of Clinical Nutrition 99, no. 1 (2014): 181-197.

Mihrshahi, S., A. J. Dobson, and G. D. Mishra. "Fruit and Vegetable Consumption and Prevalence and Incidence of Depressive Symptoms in Mid-Age Women: Results from the Australian Longitudinal Study on Women's Health.” European Journal of Clinical Nutrition 69, no. 5 (2015): $585-591$.

Prohan, Mohammad, Reza Amani, Sorur Nematpour, Nabi Jomehzadeh, and Mohammad Hossein Haghighizadeh. "Total Antioxidant Capacity of Diet and Serum, Dietary Antioxidant Vitamins Intake, and Serum Hs-CRP Levels in Relation to Depression Scales in University Male Students.” Redox Report 19, no. 3 (2014): 133-139.

Putri, Hasna Rosida, and Triska Susila Nindya. "Hubungan Kecenderungan Depresi Dengan Status Gizi Pada Lansia Di UPTD Griya Werdha Surabaya.” Media Gizi Indonesia 14, no. 1 (2019): 87-94.

Sari, Rima, Arneliwati, and Sri Utami. "Perbedaaan Tingkat Depresi Antara Lansia Yang Tinggal Di PSTW Dengan Lansia Yang Tinggal Di Tengah Keluarga” 2, no. 2 (2015).

UNAIDS. "Global Standards for Quality Health-Care Services for Adolescents: A Guide to Implement a Standards-Driven Approach to Improve the Quality of Health Care Services for Adolescents." World Health Organization 1 (2015): 1-40. http:/ /apps.who.int/iris/bitstream/10665/183935/1/9789241549332_vol1_eng.pdf. 
Kaitan Antara Depresi Dan Status Gizi Pada Lansia Di UPT Pelayanan Sosial ...

128 | FENOMENA, Vol. 20 No. 1 (Januari - Juni 2021) 